\title{
Contribution of residential wood combustion to PM10 levels in Portugal
}

\author{
C. Borrego*, J. Valente, A. Carvalho, E. Sá, M. Lopes, A.I. Miranda \\ CESAM E Department of Environment and Planning, University of Aveiro, Aveiro, Portugal
}

\section{A R T I C L E I N F O}

\section{Article history:}

Received 26 May 2009

Received in revised form

7 November 2009

Accepted 10 November 2009

\section{Keywords:}

Residential combustion

PM10 emissions

PM10 concentrations

Air quality modelling

\begin{abstract}
A B S T R A C T
Wood is commonly used in residential combustion for heating purposes; however, it can be a major source of air pollutants, namely fine particles, volatile organic compounds and carbon monoxide. Since 2004, the PM10 daily limit value has been surpassed in Portugal, and the European Commission has stated that plans and programs must be designed in order to reduce these levels. In Portugal, $18 \%$ of PM10 emissions are due to residential wood combustion, which may deeply impact the PM10 levels in the atmosphere. The main aim of this study is to investigate the impact of residential wood combustion on the air quality in Portugal. The air quality modelling system MM5/CHIMERE was applied over Portugal for a winter month, for the following three scenarios: the reference scenario, considering the actual emissions of PM10; scenario 1, where residential wood combustion emissions are not considered; and scenario 2, which takes into account a complete conversion from traditional fireplaces to certified appliances (with a $90 \%$ reduction in PM emissions). The residential wood combustion contribution to PM10 air quality concentration values during January 2007 ranges from 0 to $14 \mu \mathrm{g} \mathrm{m}^{-3}$, with a mean contribution of $10 \mu \mathrm{g} \mathrm{m}^{-3}$ in the Lisboa area and $6 \mu \mathrm{g} \mathrm{m}^{-3}$ in the Porto region. Concerning the legislated values, the area where the daily average limit value $\left(50 \mu \mathrm{g} \mathrm{m}^{-3}\right)$ is exceeded decreases by $46 \%$ in the simulation when residential combustion is not considered. The modelling results for scenario 2 are not significantly different from those for scenario 1 . In summary, the regulation of the residential wood combustion sector is as an effective way to reduce the PM10 levels in the atmosphere as regards air quality plans and programs.
\end{abstract}

(c) 2009 Elsevier Ltd. All rights reserved.

\section{Background, aim, and scope}

Particulate matter (PM) has been identified as a critical air pollution problem because of health issues associated with high concentrations. Estimates from the European Environment Agency (EEA, 2003) indicate that exposure to PM causes approximately three million deaths per year globally. Particulate matter with a $50 \%$ efficiency cut-off at $10 \mu \mathrm{m}$ aerodynamic diameter (PM10) threshold exceedances have been reported by most of the European Union (EU) member states, mainly in urban agglomerations, where human exposure is also higher (EEA, 2005).

Air quality is one of the environmental areas in which the EU has been most active, through the updating of legislation on both air quality and pollutant emissions to the atmosphere.

To reduce and control the effects of air pollution on human health and in the environment, the air quality directives require the EU member states to assess air quality throughout their territories. At the European level, the air quality Framework Directive (FD) (Directive $96 / 62 / C E$ of September 27) established the obligations of the

\footnotetext{
* Corresponding author. Tel.: +351 234370200; fax: +351 234370309.

E-mail address: cborrego@ua.pt (C. Borrego).
}

member states and redefined the guidelines for assessing and managing air quality. In May 2008, the Directive on Ambient Air Quality and Cleaner Air for Europe (Directive 2008/50/EC) was published. This directive merges four directives and one Council decision into a single directive on air quality, which introduces new objectives for fine particles, but does not change existing air quality standards. In addition, the application of numerical models is highlighted in this new FD as a fundamental tool to better assess and manage air quality.

One of the main aims of the FD is the implementation of air quality plans and programmes (PP) when air pollutant concentrations exceed the targets or limits in zones or agglomerations. The PP are implemented through the design of measures to reduce the atmospheric concentrations of air pollutants and meet the legal requirements.

Meeting the PM10 daily limit value $\left(50 \mu \mathrm{g} \mathrm{m} \mathrm{m}^{-3}\right.$, not to be exceeded more than 35 times in a calendar year) seems to be challenging for the EU Member States. In 2005, of the EU25 only Ireland did not exceed this limit value (Vixseboxse and Leeuw, 2007), and in 2006, only Ireland and Latvia from the EU27 did not exceed the limit value, with $43 \%$ of the zones and $60 \%$ of the population in the EU27 in exceedance of the limit value (Leeuw and Vixseboxse, 2007).

In Portugal over the last few years, the legislated limits for PM10 concentrations in ambient air have been surpassed at several air 
quality monitoring stations (Monteiro et al., 2007) over two agglomerations; one in the Lisboa area and the other in the Porto region, both of which were, by law, obliged to design and implement PP to reduce the PM10 concentrations in the ambient air. Furthermore, PM10 emissions in Portugal increased by $10 \%$ between 2000 and 2004, while they decreased by $10 \%$ in the rest of Western Europe.

In Portugal, the implementation of PP to reduce the PM10 concentrations in the atmosphere is being accomplished through different measures, at local to national levels. One of the measures being studied is the reduction of PM10 emissions from residential wood combustion.

Wood is commonly used in residential combustion for heating, and its use is recommended as it is a renewable energy source. However, in recent studies it has been estimated that residential wood combustion can be a major source of air pollutants, namely fine particles, volatile organic compounds (VOC) and carbon monoxide (McDonald et al., 2000; Johansson et al., 2004; Jordan and Seen, 2005; Hedberg et al., 2002). In urban areas, the effect of residential wood combustion on air quality can be significant, even though there is a strong influence of other anthropogenic sources such as traffic (Hellén et al., 2008).

Many factors influence the emissions from residential wood combustion, such as the type of wood, the structure of the fireplace or furnace (Johansson et al., 2004), the air supply, the wetness of the wood, and burning habits (Hellén et al., 2008). Johansson et al. (2004) showed that particulate matter emissions are significantly higher from a wood stove or a fireplace, i.e., from uncontrolled combustion devices, than from controlled devices. One of the most important variables that influences wood combustion emissions is the air flow supply (Jordan and Seen, 2005). Residential wood combustion impacts not only the outdoor environment, but also the indoor air quality. According to studies conducted by the United States Environmental Protection Agency (USEPA, 2009), replacing traditional fireplaces with certified wood burning appliances can result in a $90 \%$ reduction in PM emissions.

The influence of residential wood combustion on the air quality over Portugal is still poorly understood, so it is important to have a clear picture of its main characteristics.

In this study, we present the impact of residential wood combustion on atmospheric emissions and air quality. In addition, we conduct scenario analyses for Portugal to assess the influence of certified wood combustion devices as a measure to improve air quality.

\section{Data analysis}

In this section, we discuss the PM10 emissions from residential wood combustion based on the 2005 national emissions inventory (APA, 2008). In addition, a detailed analysis at several air quality stations is performed to investigate the potential impact of residential wood combustion on the monitored PM10 concentrations.

\subsection{Characterising PM10 emissions}

In Portugal, residential combustion contributes $18 \%$ of total PM10 emissions (Fig. 1a). In this sector, wood is the most common fuel (Fig. 1b), contributing 98\% of emitted PM10 (Fig. 1c).

The coastal regions of the country show the highest number of wood combustion appliances, which directly relates to the highest population density (Fig. 2a). In addition, the Centre and inner North regions also show a high number of these appliances. Northern Portugal presents the highest percentage of contribution of PM10 emissions from residential wood combustion compared to the total emitted PM10 (Fig. 2b).
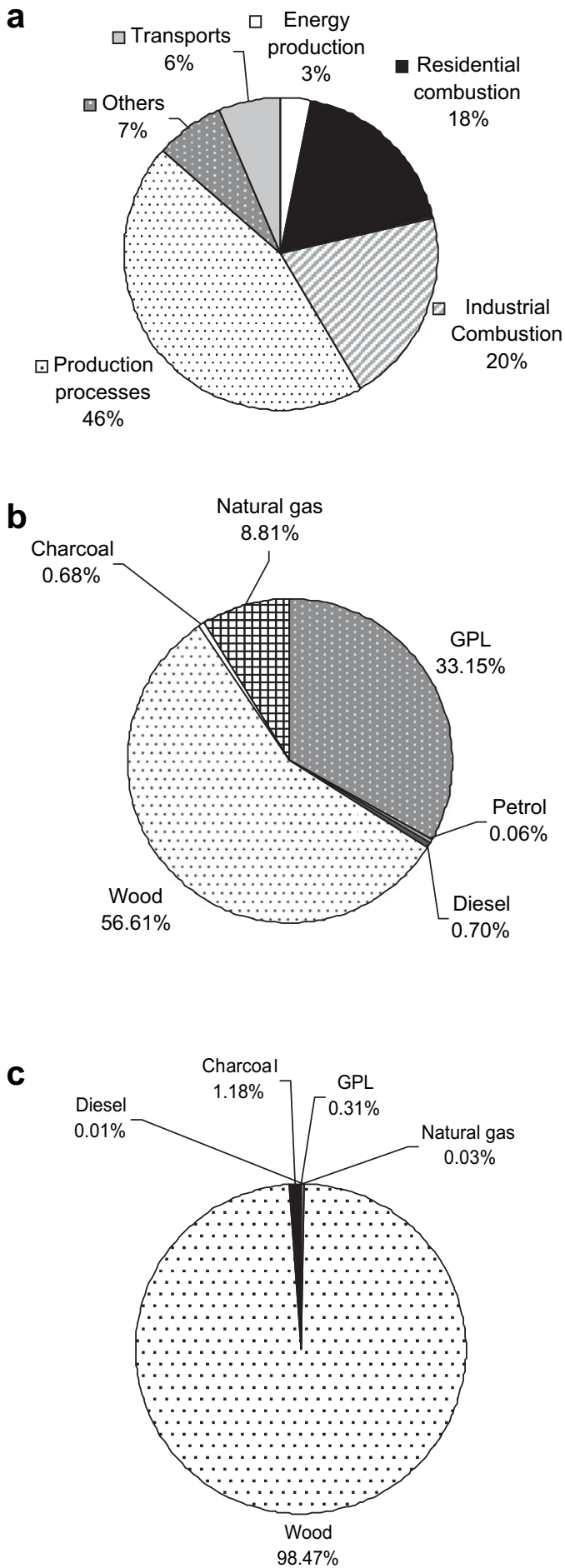

Fig. 1. a) PM10 emissions contribution by sector; b) use of energy in the residential sector by fuel type; and c) PM10 residential emissions contribution by fuel type.

\subsection{Analysing PM10 concentrations}

The PM10 concentrations in Portugal have been monitored through the air quality measuring network since 2001. Table 1 summarises the data concerning the PM10 annual average and the number of exceedances to the PM10 daily limit value (taking into account the daily limit value plus the margin of tolerance chosen by the 1999/30/CE) for several air quality stations in Portugal. These 

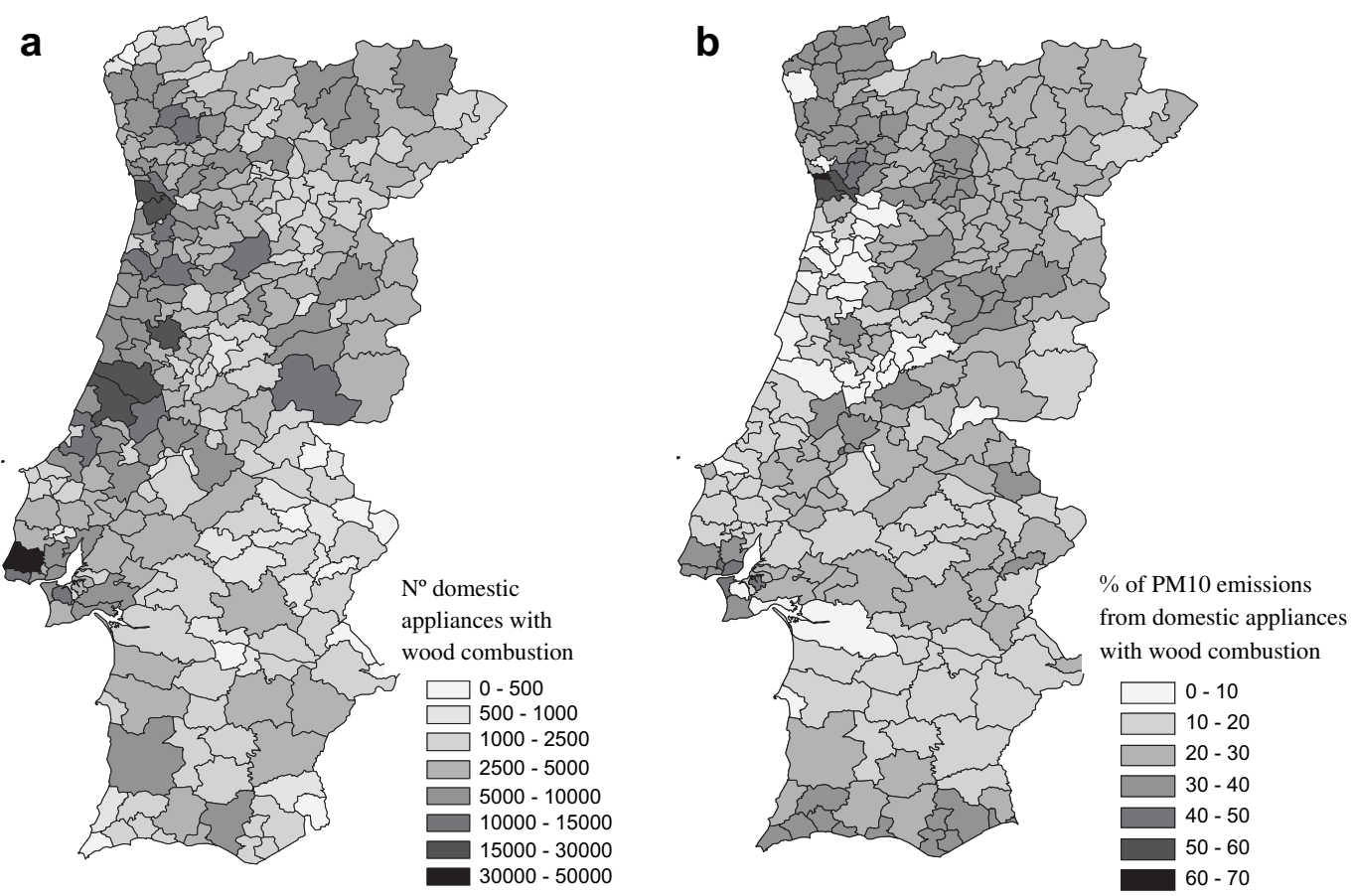

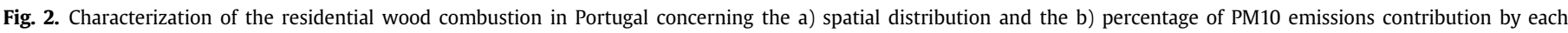
municipality.

Table 1

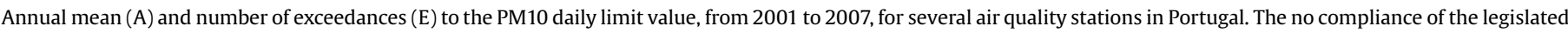
values is highlighted in grey.

\begin{tabular}{|c|c|c|c|c|c|c|c|c|c|c|}
\hline \multirow[t]{2}{*}{ Location } & \multirow[t]{2}{*}{ Station name } & \multirow[t]{2}{*}{ Station type } & & \multicolumn{7}{|l|}{ Year } \\
\hline & & & & 2001 & 2002 & 2003 & 2004 & 2005 & 2006 & 2007 \\
\hline \multirow{12}{*}{ Porto region } & \multirow[t]{2}{*}{ Ermesinde } & \multirow[t]{2}{*}{ Urban background } & A & 49.0 & 41.7 & 42.2 & 37.5 & 41.5 & 39.8 & 38.5 \\
\hline & & & $\mathrm{E}$ & 82 & 46 & 75 & 66 & 91 & 92 & 88 \\
\hline & \multirow{2}{*}{ Vila Nova da Telha } & \multirow{2}{*}{ Suburban background } & A & 45.4 & 31.7 & & 36.2 & 38.8 & 33.3 & 29.6 \\
\hline & & & $\mathrm{E}$ & 69 & 13 & & 58 & 88 & 56 & 36 \\
\hline & \multirow[t]{2}{*}{ Leça do Balio } & \multirow[t]{2}{*}{ Suburban background } & A & 54.4 & 43.9 & 45.9 & 36.8 & 36.1 & & 38.5 \\
\hline & & & $\mathrm{E}$ & 85 & 62 & 97 & 71 & 79 & & 78 \\
\hline & \multirow[t]{2}{*}{ Antas } & \multirow[t]{2}{*}{ Urban traffic } & A & & 57.5 & 46.8 & 41.4 & 41.1 & 36.3 & 35.2 \\
\hline & & & $\mathrm{E}$ & & 134 & 99 & 73 & 93 & 72 & 62 \\
\hline & \multirow[t]{2}{*}{ Vila do Conde } & \multirow[t]{2}{*}{ Suburban traffic } & A & & & 54.6 & 55.0 & 51.1 & 45.8 & 43.3 \\
\hline & & & $\mathrm{E}$ & & & 128 & 159 & 158 & 112 & 115 \\
\hline & \multirow[t]{2}{*}{ Espinho } & \multirow[t]{2}{*}{ Urban traffic } & A & & 51.4 & 54.0 & 53.1 & 47.3 & 42.6 & 43.5 \\
\hline & & & $\mathrm{E}$ & & 80 & 109 & 122 & 128 & 88 & 130 \\
\hline \multirow[t]{10}{*}{ Aveiro region } & \multirow[t]{2}{*}{ Av. Fernão Magalhães - Coimbra } & \multirow[t]{2}{*}{ Urban traffic } & A & & 46.1 & 50.1 & 44.9 & 48.5 & & \\
\hline & & & $\mathrm{E}$ & & 55 & 95 & 118 & 95 & & \\
\hline & \multirow[t]{2}{*}{ Estarreja } & \multirow[t]{2}{*}{ Suburban industrial } & A & & 31.5 & 42.0 & 42.0 & 40.6 & 35.4 & 38.0 \\
\hline & & & $\mathrm{E}$ & & 15 & 90 & 92 & 105 & 76 & 80 \\
\hline & \multirow[t]{2}{*}{ Ílhavo } & \multirow[t]{2}{*}{ Rural background } & A & & & 34.9 & & 28.0 & 28.1 & 28.1 \\
\hline & & & $\mathrm{E}$ & & & 31 & & 29 & 40 & 40 \\
\hline & \multirow[t]{2}{*}{ Aveiro } & \multirow[t]{2}{*}{ Urban traffic } & A & & & 44.1 & 38.1 & 38.3 & 33.8 & 40.9 \\
\hline & & & $\mathrm{E}$ & & & 65 & 61 & 76 & 52 & 96 \\
\hline & \multirow[t]{2}{*}{ Instituto Geofísico de Coimbra } & Urban background & A & & & 35.9 & & 28.3 & 29.4 & 27.4 \\
\hline & & & $\mathrm{E}$ & & & 38 & & 31 & 31 & 29 \\
\hline Lisboa region & Entrecampos & Urban/traffic & A & 41.1 & 41.8 & 46.2 & 47.5 & 44.1 & 40.7 & 36.9 \\
\hline & & & $\mathrm{E}$ & 38 & 35 & 81 & 89 & 111 & 87 & 72 \\
\hline & Loures & Urban background & A & & 35.7 & 36.3 & 32.4 & 32.8 & 31.1 & 28.2 \\
\hline & & & $\mathrm{E}$ & & 22 & 43 & 45 & 43 & 47 & 25 \\
\hline & Escavadeira & Urban industrial & A & & 40.3 & 42.7 & 40.9 & 36.9 & 38.7 & 39.8 \\
\hline & & & $\mathrm{E}$ & & 43 & 86 & 82 & 78 & 83 & 96 \\
\hline & Cascais & Urban traffic & A & & & 52.2 & 41.7 & 40.9 & 38.5 & 36.8 \\
\hline & & & $\mathrm{E}$ & & & 112 & 61 & 83 & 56 & 46 \\
\hline & Olivais & Urban background & A & 33.1 & 28.8 & 29.2 & 31.9 & 30.3 & 30.6 & 28.0 \\
\hline & & & $\mathrm{E}$ & 19 & 8 & 20 & 47 & 43 & 48 & 23 \\
\hline
\end{tabular}

A - annual mean; E - number of exceedances to the daily limit value plus margin of tolerance. 
stations are located in the three main polluted regions in Portugal (Fig. 3) and are representative of different types of pollution (traffic, industrial and background) and environments (urban, suburban and rural).

According to Table 1, most of the stations from the Porto to Lisboa regions do not comply with the legislated PM10 limits. All of the traffic stations (urban and suburban) show a number of exceedances to the PM10 daily limit value, always above the legislated limits. Background stations also show a higher number of exceedances than allowed, depending on the region and year. In terms of PM10 annual means, the Porto region presents higher values than the Aveiro and Lisboa regions. On average, the number of exceedances is also higher in Porto than in Lisboa and Aveiro. The large values shown in Table 1 stress the air quality problem that Portugal faces regarding PM10 levels in the atmosphere.

For a detailed analysis of the measured PM10 concentrations, different air quality monitoring stations have been selected in order to guarantee an adequate spatial coverage, especially for the regions
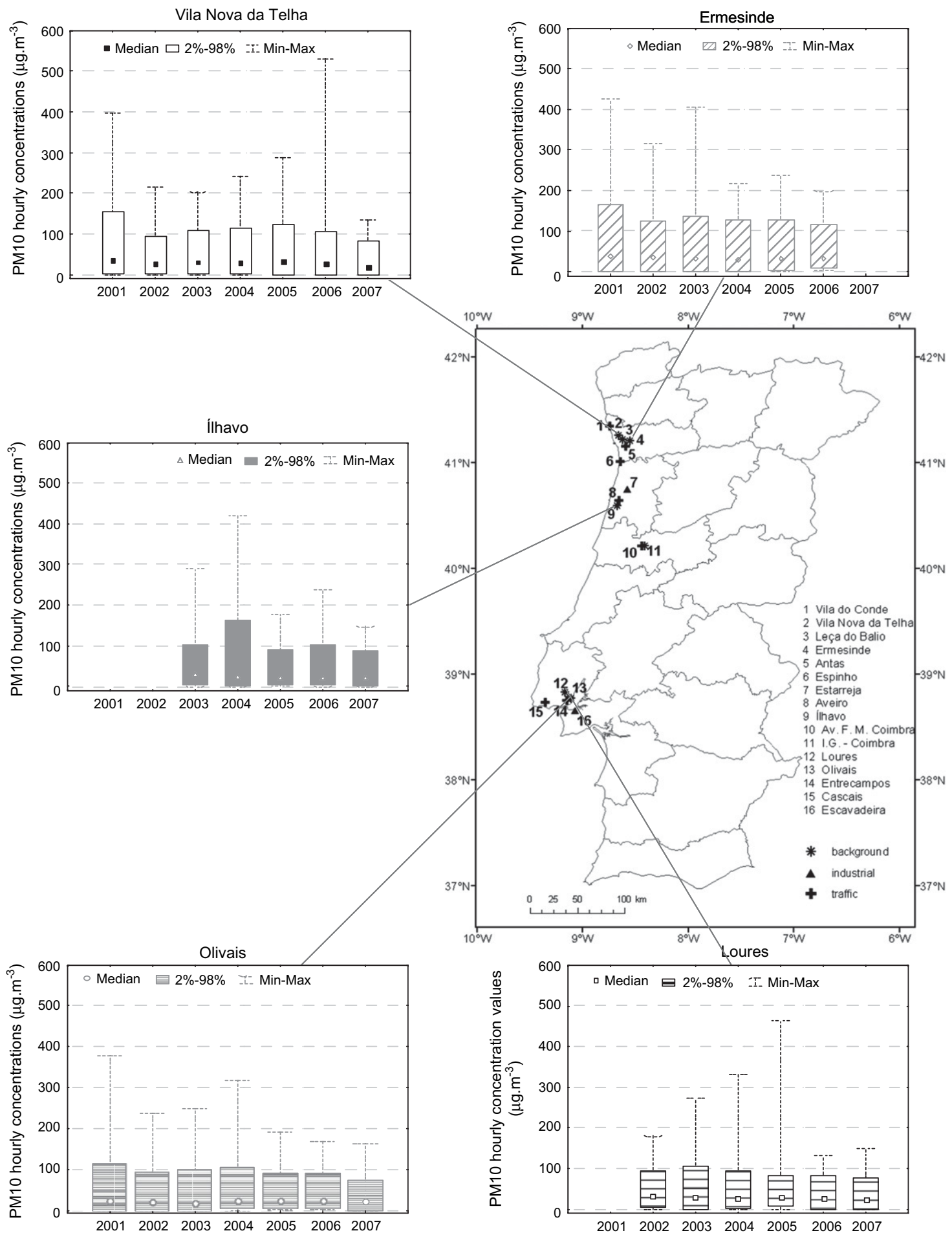

Fig. 3. Identification and location of the selected air quality stations and annual variations in the hourly PM10 measurements at the select air quality stations. 
where there are more combustion appliances, for a long time period and according to their classification, namely rural, suburban and urban. In this sense, the background stations of Vila Nova da Telha, Ermesinde (Porto region), lllhavo (Aveiro region), Olivais and Loures (Lisboa region) (Fig. 3) have been selected. These locations were chosen because background stations have the highest spatial representativeness. The monitoring period between 2001 and 2007 was used for the analysis of the hourly PM10 concentration. Box and whisker plots are presented for the selected sites to explore their temporal patterns. The PM10 concentrations vary according to the season, the day of the week, and the time of day. Meteorological conditions in combination with variations in emissions on many different time scales contribute to these temporal patterns. The annual distributions of PM10 concentrations at the selected sites between 2001 and 2007 are summarised in Fig. 3.

Fig. 3 shows that, of all of the selected stations, only Vila Nova da Telha and Olivais provide data for the full analysis period. The highest hourly concentration was registered at the Vila Nova da Telha station, reaching almost $550 \mu \mathrm{g} \mathrm{m}^{-3}$. For the analysed sites, the 98th percentile presents the highest values in the northern stations of Vila Nova da Telha and Ermesinde. For the other stations, the 98th percentile is below $100 \mu \mathrm{g} \mathrm{m}^{-3}$, except in 2004 at Ílhavo station. A trend analysis is not possible due to the short time period being analysed. It is important to note that part of the variation in year to year concentrations of PM10 is due to interannual climate variability, since meteorological conditions will favour dispersion in some years and not others. The time series presented here have not been de-climatised to adjust for this factor.

Fig. 4a presents the monthly distribution of the PM10 hourly concentrations for the selected air quality stations and for the full period between 2001 and 2007. The winter months show the highest range of values between the 2 nd and 98 th percentiles. In addition, the month of January presents the highest values for the upper extreme (98th percentile). It should be noted that the months of August and September also register high PM10 concentrations; this can be directly related to forest fire activity (Miranda et al., 2007). In Portugal, 2003 and 2005 registered the highest amounts of area burned for the last decades, deeply impacting the air pollutant levels for ozone, nitrogen oxides and PM10.

On a hebdomadal (day-of-week) basis (Fig. 4b), the analysed sites do not present any difference between the PM10 concentrations measured on the weekdays and the weekend. The presented analysis does not reveal any influence of specific sources, like traffic or industrial/commercial sources, that could support the weekly pattern.

The diurnal average pattern for each station was determined for each season (Fig. 5). All monitoring stations indicate, especially in the winter and in autumn, two peaks in average concentration: one in the morning between 7 and $11 \mathrm{am}$, and the other in the evening between 7 and $10 \mathrm{pm}$, the latter being considerably higher at all analysed sites. This evidence is visible at the urban environment stations (Olivais, Loures and Ermesinde) as well as at the suburban stations (Vila Nova da Telha and Ílhavo). The exact timing of the peak concentration varies from location to location. Concentrations decrease during the day from mid-morning to early evening. At night, the decrease occurs following the evening peak between midnight and roughly $5 \mathrm{am}$. The amplitude of variation is higher at night than during the afternoon.

The existence of morning and evening peak of PM10 concentrations could be the result of increased vehicle and residential emissions, such as home heating during the early morning and evening hours. A comparison among the different daily profiles obtained for each season reveals that the PM10 concentration peaks detected in the winter are more pronounced than in the other seasons. At the Ílhavo air quality station, the daily pattern of PM10 concentrations is much more pronounced in the winter. On the
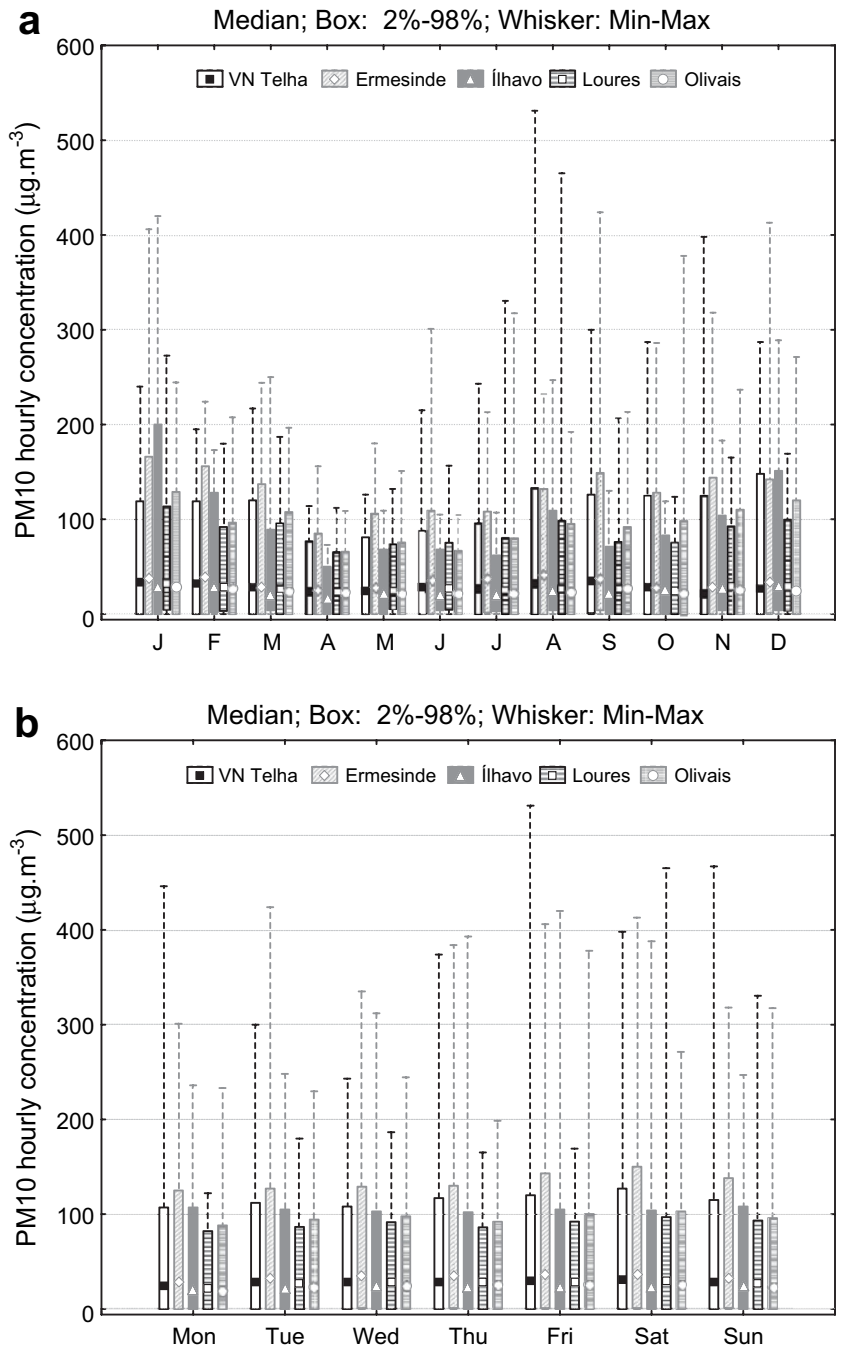

Fig. 4. a) Monthly distribution and b) hebdomadal variations in hourly PM10 measurements at the selected air quality stations.

other hand, in the summer, the daily average profile is smoother, and the night time peak is considerably lower.

\section{Air quality modelling}

To study the influence of the residential wood combustion emissions on PM10 concentrations, we applied the air quality modelling system MM5/CHIMERE over Portugal for winter conditions.

\subsection{Air quality modelling system}

The applied air quality modelling system is based on the chemistry-transport model CHIMERE (Schmidt et al., 2001; Bessagnet et al., 2004), forced by the mesoscale model MM5 (Grell et al., 1994). The MM5/CHIMERE modelling system has been widely applied and validated in several air quality studies in Portugal (Monteiro et al., 2005, 2007), and it is currently used as the Portuguese air quality forecasting system.

The MM5 mesoscale model is a nonhydrostatic, vertical sigmacoordinate model designed to simulate mesoscale atmospheric circulations. MM5 has multiple nesting capabilities, a four-dimensional data assimilation capability, and a large variety of physical options. The selected MM5 physical options were based on validation 

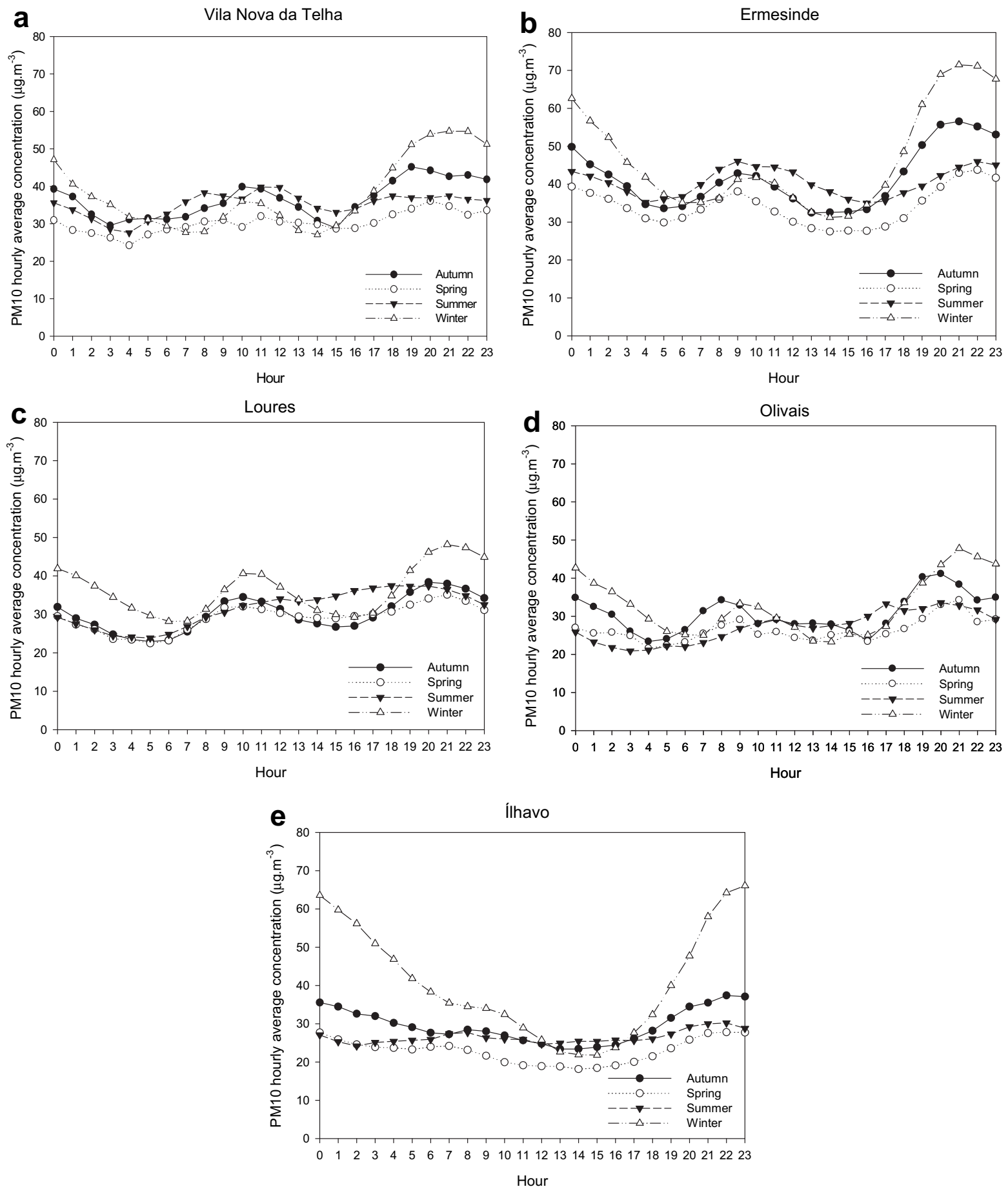

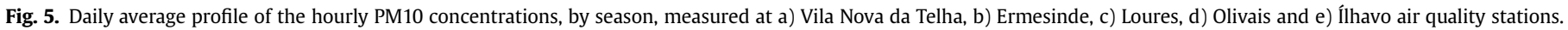

and sensitivity studies previously preformed for Portugal (Aquilina et al., 2005; Carvalho et al., 2006). The MM5 model generates the several meteorological fields required by the CHIMERE model, including the wind, temperature, water vapour mixing ratio, cloud liquid water content, $2 \mathrm{~m}$ temperature, surface heat, moisture fluxes and precipitation.

CHIMERE is a three-dimensional chemistry-transport model, based on the integration of the continuity equation for the concentrations of several chemical species in each cell of a given grid. It was developed for simulating gas-phase chemistry (Schmidt et al., 2001), and aerosol formation, transport and deposition (Bessagnet et al.,
2004; Vautard et al., 2005) at regional and urban scales. The meteorological input variables driven by the MM5 model are linearly interpolated into the CHIMERE grid. In addition to the meteorological input, the CHIMERE model needs boundary and initial conditions, emission data, and land use and topography characterisation. The non-methane volatile organic compounds (NMVOC) are disaggregated into 227 individuals VOCs according to the speciation suggested by Passant (2002) for each activity sector. The methodology for biogenic emissions of isoprene and terpenes is described in Schmidt et al. (2001). The land use database comes from the Global Land Cover Facility (Hansen et al., 2000) and provides grid cell 
coverage of coniferous and broadleaf forests. The Stohl et al. (1996) methodology is used for the biogenic emissions of nitrogen monoxide (NO) from fertilised soils. The model simulates the concentrations of 44 gaseous species and six aerosol chemical compounds. The aerosol model accounts for both inorganic and organic species, of primary or secondary origin, such as primary particulate matter (PPM), sulphates, nitrates, ammonium, secondary organic species (SOA) and water.

\subsection{Air quality modelling application}

The MM5/CHIMERE modelling system was first applied at the European scale (with a $50 \times 50 \mathrm{~km}^{2}$ resolution) and then over Portugal using the same physics and a one-way nesting technique, with a $10 \times 10 \mathrm{~km}^{2}$ horizontal resolution. The European domain covers an area from $14^{\circ} \mathrm{W}$ to $25^{\circ} \mathrm{E}$ and $35^{\circ} \mathrm{N}$ to $58^{\circ} \mathrm{N}$. Over Portugal, the simulation domain extends from $9.5^{\circ} \mathrm{W}$ to $6^{\circ} \mathrm{W}$ and $37^{\circ} \mathrm{N}$ to $42.5^{\circ} \mathrm{N}$. Table 2 presents the domain definition and the physical options selected for the MM5/CHIMERE application.

The MM5/CHIMERE modelling system requires hourly spatially resolved emissions for the main anthropogenic gas and aerosol species. For the large-scale simulation (over Europe), the anthropogenic emissions for nitrogen oxides $\left(\mathrm{NO}_{\mathrm{x}}\right)$, carbon monoxide $(\mathrm{CO})$, sulphur dioxide $\left(\mathrm{SO}_{2}\right)$, non-methane volatile organic compounds (NMVOC) and ammonia $\left(\mathrm{NH}_{3}\right)$ gas-phase species and for PM2.5 and PM10 are provided by the European Monitoring and Evaluation Programme (EMEP) (Vestreng, 2003) with a spatial resolution of $50 \mathrm{~km}$. There is no chemical speciation for PM emissions. For the fine scale Portuguese domain, the 2005 national inventory report (APA, 2008) was used. This inventory has been improved to take into account a more detailed PM inventory for wood burning.

The inventory takes into account annual emissions from line sources (streets and highways), area sources (industrial and residential combustion, solvents and others) and large point sources. These annual emission data for each type of pollutant activity were spatially disaggregated in order to obtain the resolution required for the Portuguese domain simulation. The disaggregation is done in two steps. First, emissions are estimated at the municipality level using adequate statistical indicators for each pollutant activity (e.g., types of fuel consumptions) and then distributed according to the population density (Monteiro et al., 2007). Time disaggregation was done by applying monthly, weekly and hourly profiles from the University of Stuttgart (GENEMIS, 1994). The PM inventory for wood burning was created following a bottom-up methodology. A survey at the national level was performed to determine burning habits, concerning the type of wood, quantities burned and time of burn, and types of wood burner appliances used. These emissions have been estimated at the municipality level. The total PM emissions are in accordance with the

Table 2

MM5 and CHIMERE simulation definitions.

\begin{tabular}{llll}
\hline & & $\begin{array}{l}\text { European } \\
\text { domain }(\mathrm{D} 1)\end{array}$ & $\begin{array}{l}\text { Portuguese } \\
\text { domain (D2) }\end{array}$ \\
\hline MM5 & Dimensions $(X, Y)$ & $96 \times 81$ cells & $73 \times 109$ cells \\
& Horizontal resolution & $54 \mathrm{~km}$ & $9 \mathrm{~km}$ \\
& Vertical resolution & 32 sigma levels & 32 sigma levels \\
& Physics & MRF PBL scheme & MRF PBL scheme \\
& & RRTM radiation & RRTM radiation \\
& & scheme & scheme \\
& & Grell cumulus & Grell cumulus \\
& scheme & scheme \\
& & Graupel moisture & Graupel moisture \\
& & scheme & scheme \\
& & $46 \times 67$ cells & $29 \times 58$ cells \\
CHIMERE & Dimensions $(X, Y)$ & 50 km & 10 km \\
& Horizontal resolution & 8 levels & 8 levels \\
& Vertical resolution & Melchior & Melchior \\
\hline & Chemical mechanism & Melchel & \\
& & &
\end{tabular}

results from the national inventory; results show that emissions were overestimated in coastal areas and underestimated in the interior of the country. This is because the national inventory did not take into account burning habits. A specific temporal profile was created for the emissions of PM from the domestic sector to take into account wood burning habits in Portugal.

The MM5/CHIMERE simulations were conducted for January 2007. January was chosen because it is, climatologically, the coldest month in Portugal (SMN, 1974). Also, from Fig. 4a we concluded that January is the month of the year with the highest PM10 mean and peak values at almost all of the analysed air quality monitoring stations. The modelling study was conducted for 2007 , since it was the most recent year with available data. The simulation design comprised a reference simulation and two scenarios. The reference simulation consisted in applying the MM5/CHIMERE system, including emissions from all sectors, while scenario 1 is a simulation with no residential wood combustion emissions and scenario 2 is a simulation with a complete replacement of traditional fireplaces by certified wood burning appliances. For this scenario, a 90\% PM10 emission reduction was considered for the residential combustion sector. It was then possible to estimate the contribution of residential wood combustion in PM10 concentrations, as well as to analyse the effect of the use of certified wood combustion appliances.

\subsection{Air quality modelling results}

The spatial distribution of monthly PM10 average concentrations over the Portuguese national territory is depicted in Fig. 6a. Fig. $6 \mathrm{~b}$ shows the monthly average PM10 reduction achieved when no residential combustion is considered in the air quality simulation (scenario 1). The scenario 2 (certified combustion appliances) modelling results are shown in Fig. $6 \mathrm{c}$.

The modelling results confirm the conclusion drawn from the PM10 measurements: in the reference situation (Fig. 6a), high values of PM10 are achieved in the coastal areas, particularly in the Porto and Lisboa areas, the two largest population centres in Portugal. For the reference situation, simulations and observations of PM10 were compared for the selected monitoring sites. The model's skill was evaluated using statistical measures such as the bias, normalised errors, and correlation coefficients (Borrego et al., 2008). Despite an underestimation of the simulated PM10 concentrations revealed by the bias values (varying from 9.1 to $15.4 \mu \mathrm{g} \mathrm{m}^{-3}$ ), their time variations are relatively well captured by the model at the different monitoring sites. The model shows reasonable agreement with observations, with correlation coefficients between 0.4 and 0.6 and normalised errors between $20 \%$ and $45 \%$. The statistical values obtained are within the range found in the evaluation of the simulation of PM10 mass concentration values using different chemical transport models (Vautard et al., 2007; Stern et al., 2008).

For the reference simulation, it can be seen that the average monthly PM10 concentrations reach almost $54 \mu \mathrm{g} \mathrm{m}^{-3}$ in the northern part of the country over the Porto region. Fig. $6 \mathrm{~b}$ shows that the contribution of residential wood combustion to the PM10 levels is also higher in the coastal areas, a fact that agrees with the spatial distribution of heating appliances (Fig. 2a). This contribution ranges from 0 to $14 \mu \mathrm{g} \mathrm{m}^{-3}$, with a mean value of $10 \mu \mathrm{g} \mathrm{m}^{-3}$ in the Lisboa area, $6 \mu \mathrm{g} \mathrm{m}^{-3}$ in the Porto region and $3 \mu \mathrm{g} \mathrm{m}^{-3}$ in Aveiro. Scenario 1 (Fig. 6b) simulation results are not significantly different from scenario 2 (Fig. 6c); nevertheless, scenario 1 presents larger areas with higher reductions in the PM10 monthly average concentrations.

Concerning the fulfilment of the PM10 legislation, Fig. 7 presents the number of grid-square PM10 daily concentrations above $50 \mu \mathrm{g} \mathrm{m}^{-3}$ for January 2007 for the reference simulation (Fig. 7a), for scenario 1 (no residential wood combustion) (Fig. 7b) and scenario 2 (certified combustion appliances) (Fig. 7c). 


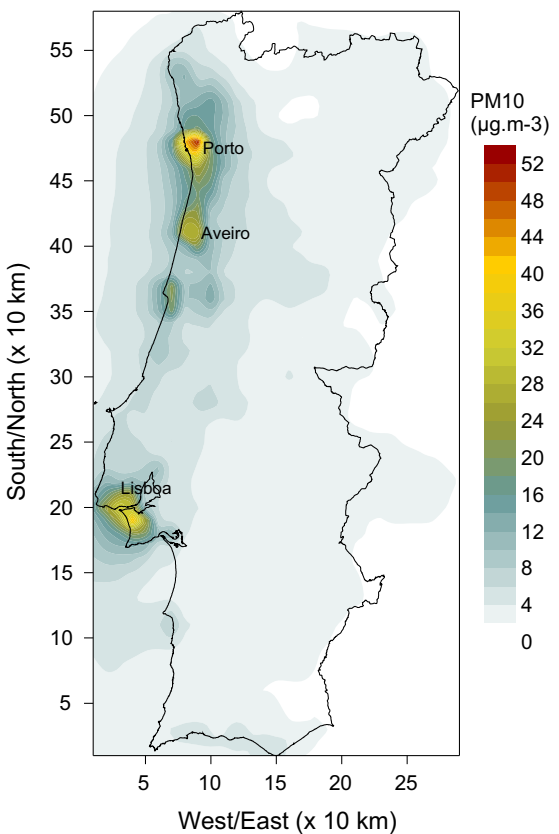

a

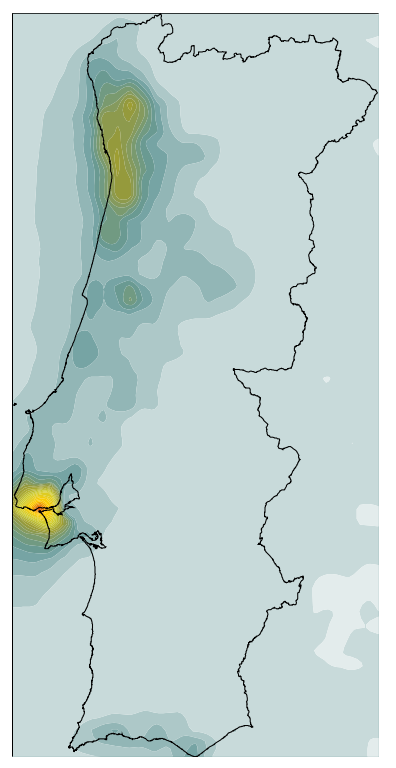

PM10 reduction ( $\mu \mathrm{g} \cdot \mathrm{m}-3)$

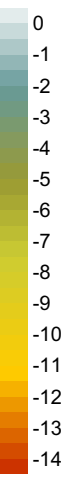

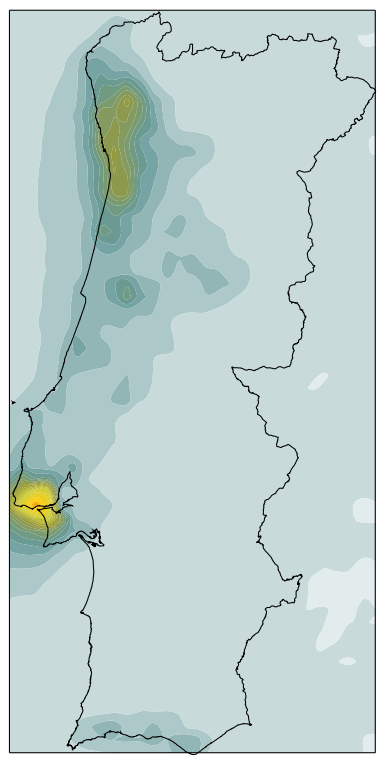

C

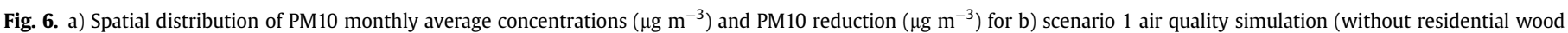
combustion emissions) and for c) scenario 2 simulation (certified combustion appliances).

The analysis of Fig. 7 allows us to identify the areas where the daily limit value (coloured areas) is exceeded. From Fig. 7a and b, it can be seen that the grid-square where the legislated daily limit value $\left(50 \mu \mathrm{g} \mathrm{m}^{-3}\right.$ ) is exceeded is reduced in $46 \%$ when residential combustion emissions are not considered. The number of exceedances decreases from 128 in the reference simulation to 64 and 69 in scenarios 1 and 2, respectively. Although the highest contribution of PM10 emissions from residential combustion is found in the
Lisboa area, it can be seen that, concerning the fulfilment of air quality legislation, its impacts are higher in the northern regions of the country.

To evaluate the distribution of PM10 concentrations (for each simulation) over the regions where higher values are attained, the cumulative frequency distribution is presented in Fig. 8 for the Porto, Aveiro and Lisboa regions. The distribution for scenario 2 is not depicted because it closely follows and even overlaps scenario 1.

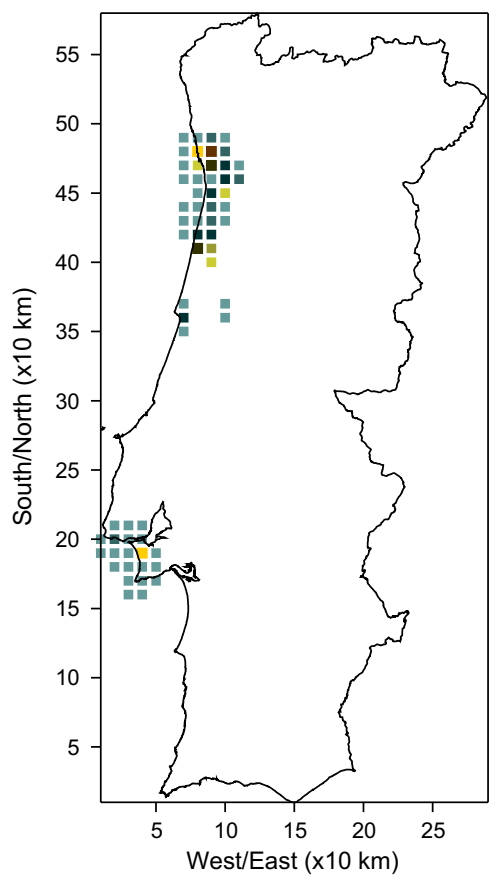

a

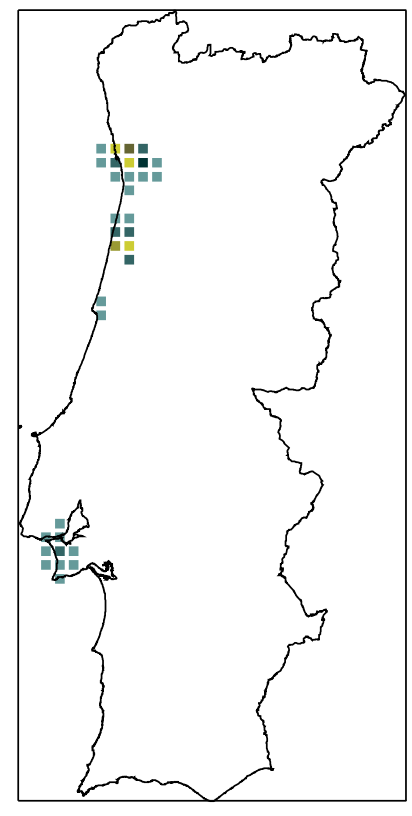

b

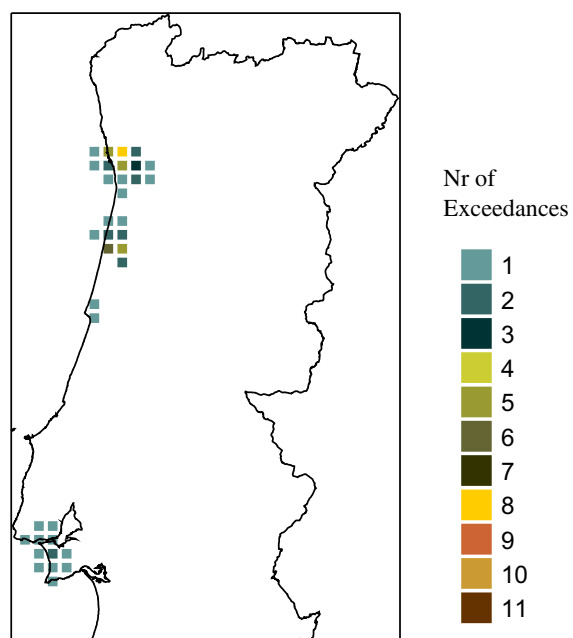

C

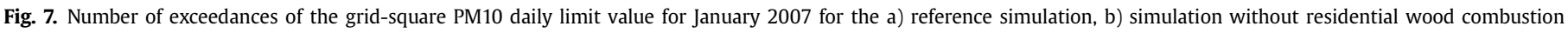
emissions (scenario 1) and c) simulation with certified combustion appliances (scenario 2). 

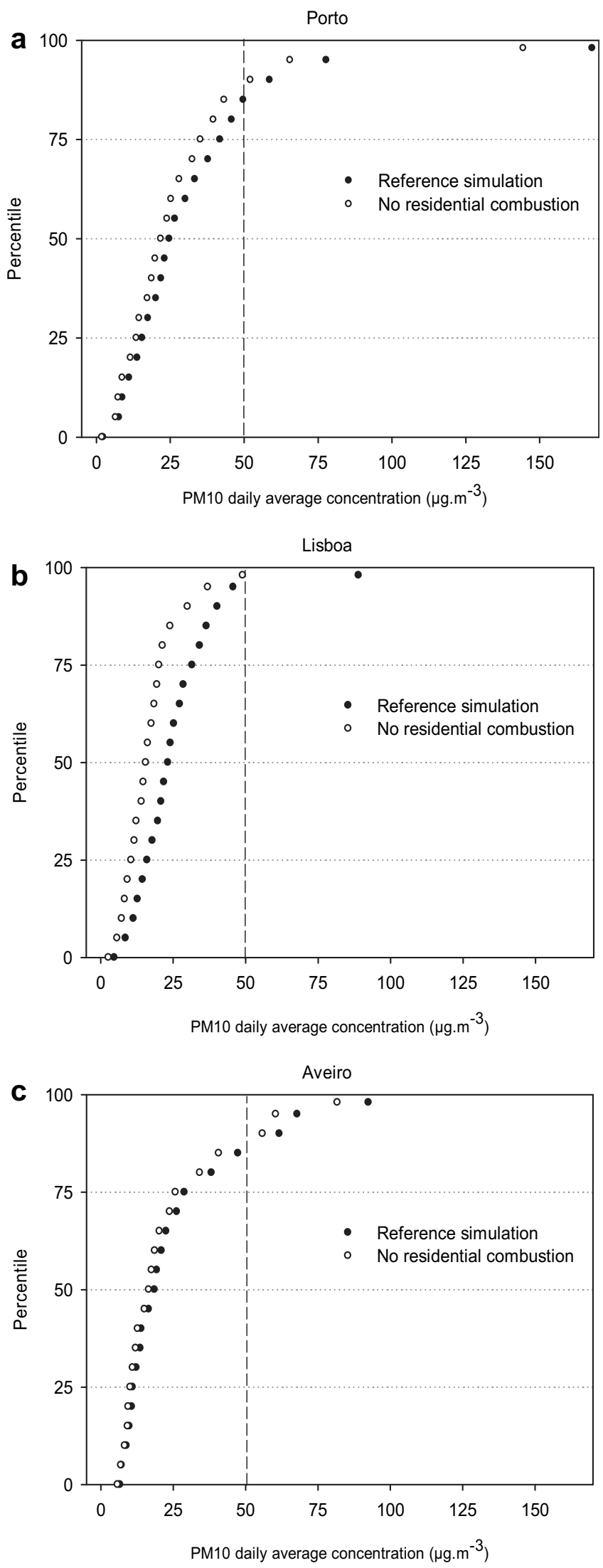

Fig. 8. Cumulative frequency distribution of the PM10 daily average concentrations for a) Porto; b) Lisboa, and c) Aveiro regions.
According to Fig. 8, the reduction in PM10 concentrations is highest in the Lisboa region where, for instance, the 75th percentile decreases from 31 to $20 \mu \mathrm{g} \mathrm{m}^{-3}$. For the simulation without emissions from residential combustion, the 98th percentile decreases to values that are below the legislated daily limit value. For the Porto region, the PM10 concentrations show a decrease mostly above the 60th percentile of approximately $5 \mu \mathrm{g} \mathrm{m}^{-3}$. The 98 th percentile shows a decrease of $23 \mu \mathrm{g} \mathrm{m}^{-3}$ from the reference to the scenario 1 simulation. Above the 90th percentile, both simulations surpass the defined limit value. For the Aveiro region, the cumulative distribution of PM10 concentrations does not present a significant reduction, although the 98th percentile registers a decrease of almost $10 \mu \mathrm{g} \mathrm{m}^{-3}$. The residential wood combustion emissions clearly influence the PM10 concentrations in the analysed regions, although in Porto and Aveiro other sources contribute to the attained PM10 levels. The daily limit value is still surpassed in these parts of Portugal.

\section{Summary and conclusions}

High levels of PM10 are attained in Portugal, particularly on the west coast. This has already led to the necessity of designing and implementing plans and programs for reducing PM10 levels in the ambient air over the Lisboa and Porto regions. The fact that these concentrations are higher in the winter and at night highlights the possibility that PM10 emissions from residential wood burning play an important role in the concentration levels reached in the winter. The main objective of this paper is to study the contribution of residential wood burning to PM10 levels, as well as to assess the influence of the use of certified wood combustion appliances.

From this study, we conclude that residential wood combustion has a significant contribution to the PM10 concentrations in the winter, attaining mean values of $10 \mu \mathrm{g} \mathrm{m}^{-3}$ in the Lisboa region and $6 \mu \mathrm{g} \mathrm{m}^{-3}$ in the Porto area. This is in accordance with Puxbaum et al. (2007), who concluded that biomass smoke is the predominant organic aerosol constituent in the winter in mid and Western Europe. These authors also found that, from all of the studied locations, the Portuguese site was the one registering the most pronounced seasonality in the contribution of biomass burning to PM levels, with the highest concentrations in the winter and the lowest in the summer. These findings are also in accordance with studies on other European areas. Caseiro et al. (2009) found that in the larger Vienna region, wood smoke was an important contributor to PM10 during the cold season, with contributions around 10\% during the winter months, and Favez et al. (2009) estimated that the contribution of wood burning carbonaceous aerosols to PM2.5 was around 20\% at the studied Paris background site.

Slightly differences in PM10 concentrations have been detected when comparing air quality simulations considering certified wood burning devices and not considering residential wood combustion, namely in the number of exceedances to the daily limit value. Therefore, the conversion of traditional fireplaces to certified devices seems a feasible measure with a significant contribution to better air quality in terms of PM10 concentrations. In fact, it is estimated that the area where the daily maximum exceeds $50 \mu \mathrm{g} \mathrm{m}^{-3}$ would decrease by half in the absence of residential wood combustion emissions. In Portugal, residential wood combustion contributes almost $18 \%$ of total PM10 emissions, and these emissions are concentrated mainly in the winter.

The fact that this is an unregulated sector should be seen as an opportunity to step in and regulate or legislate. This option will not solve all PM10 problems but can provide an important contribution, particularly in the winter, and should be used in an integrated approach with additional mitigation measures. The methodology used in this work allows its usage for further locations and as support for policy decisions for better air quality. 


\section{Acknowledgements}

The authors thank the 3rd EU Framework Program and the Portuguese 'Ministério da Ciência, da Tecnologia e do Ensino Superior' for financial support for the Project PAREXPO (POCI/AMB/57393/ 2004) and the Ph.D. grant of J. Valente (SFRH/BD/22687/2005). The support from the ACCENT Network of Excellence (GOCE/CT/2004/ 505337) is also acknowledged.

\section{References}

APA (Agência Portuguesa do Ambiente), 2008. Alocação Espacial de Emissões em 2005: Gases Acidificantes, Eutrofizantes e Precursores de Ozono Partículas, Metais Pesados e Gases com Efeito de Estufa. Available online at: http://www. apambiente.pt/politicasambiente/Ar/InventarioNacional/Documents/Inventory_ Brochure_20080919a.pdf.

Aquilina, N., Dudek, A.V., Carvalho, A., Borrego, C., Nordeng, T.E., 2005. MM5 high resolution simulations over Lisbon. Geophysical Research Abstracts. SRef-ID: 1607-7962/gra/EGU05-A-08685. European Geosciences Union, 7: 08685.

Bessagnet, B., Hodzic, A., Vautard, R., Beekmann, M., Cheinet, S., Honoré, C., Liousse, C., Rouil, L., 2004. Aerosol modelling with CHIMERE - preliminary evaluation at the continental scale. Atmospheric Environment 38, 2803-2817.

Borrego, C., Monteiro, A., Ferreira, J., Miranda, A.I., Costa, A.M., Carvalho, A.C. Lopes, M., 2008. Procedures for estimation of modelling uncertainty in air quality assessment. Environment International 34, 613-620.

Carvalho, A.C., Carvalho, A., Gelpi, I., Barreiro, M., Borrego, C., Miranda, A.I., PerezMunuzuri, V., 2006. Influence of topography and land use on pollutants dispersion in the Atlantic coast of Iberian Peninsula. Atmospheric Environment 40, 3969-3982.

Caseiro, A., Bauer, H., Schmidl, C., Pio, C.A., Puxbaum, H., 2009. Wood burning impact on PM10 in three Austrian regions. Atmospheric Environment 43, 2186-2195.

EEA (European Environment Agency), 2003. Europe's Environment: the Third Assessment. EEA, Copenhagen, ISBN 92-9167-574-1.

EEA (European Environment Agency), 2005. The European environment - state and outlook 2005. State of Environment report No 1/2005, Copenhagen.

Favez, O., Cachier, H., Sciare, J., Sarda-Estève, R., Martinon, L., 2009. Evidence for a significant contribution of wood burning aerosols to PM2.5 during the winter season in Paris, France. Atmospheric Environment 43, 3640-3644.

GENEMIS (Generation of European Emission Data for Episodes), 1994. Project: EUROTRAC Annual Report, 1993, Part 5. EUROTRAC International Scientific Secretariat, Garmisch-Partenkirchen.

Grell, G.A., Dudhia, J., Stauffer, D.R., 1994. A Description of the Fifth-generation Penn State/NCAR Mesoscale Model (MM5). Tech. Rep. NCAR/TN-398+STR. Natl. Cent. for Atmos. Res., Boulder, Colorado.

Hansen, M.C., DeFries, R.S., Townsend, J.R., Sohlberg, R., 2000. Global land cover classification at $1 \mathrm{~km}$ spatial resolution using a classification tree approach. International Journal of Remote Sensing 21, 1331-1364.

Hedberg, E., Kristensson, A., Ohlsson, M., Johansson, C., Johansson, PÅ., Swietlicki, E., Vesely, V., Wideqvist, U., Westerholm, R., 2002. Chemical and physical characterization of emissions from birch wood combustion in a wood stove. Atmospheric Environment 36, 4823-4837.

Hellén, H., Hakola, H., Haaparanta, S., Pietarila, H., Kauhaniemi, M., 2008. Influence of residential wood combustion on local air quality. Science of Total Environment 393, 283-290.
Johansson, L.S., Leckner, B., Gustavsson, L., Cooper, D., Tullinh, C., Potter, A., 2004. Emission characteristics of modern and old-type residential boilers fired with wood logs and wood pellets. Atmospheric Environment 38, 4183-4195.

Jordan, T.B., Seen, A.J., 2005. Effect of airflow setting on the organic composition of woodheater emissions. Environmental Science and Technology 39, 36013610.

Leeuw, F., Vixseboxse, E., 2007. Reporting on Ambient Air Quality Assessment. Preliminary Results for 2006. European Topic Centre on Air and Climate Change (ETC/ACC) ETC/ACC Technical Paper 2007/5 December 2007. Netherlands Environmental Assessment Agency (MNP), Bilthoven, The Netherlands.

McDonald, J.D., Zielinska, B., Fujita, E.M., Sagebiel, J.C., Chow, J.C., Watson, J.G., 2000. Fine particle and gaseous emission rates from residential wood combustion. Environmental Science and Technology 34, 2080-2091.

Miranda, A.I., Monteiro, A., Martins, V., Carvalho, A., Schaap, M., Builtjes, P., Borrego, C., 2007. Forest fires impact on air quality over Portugal. In: Borrego, C., Miranda, A.I. (Eds.), Air Pollution Modeling and Its Application XIX. Springer, Netherlands.

Monteiro, A., Vautard, R., Borrego, C., Miranda, A.I., 2005. Long-term simulations of photo oxidant pollution over Portugal using the CHIMERE model. Atmospheric Environment 39, 3089-3101.

Monteiro, A., Miranda, A.I., Borrego, C., Vautard, R., Ferreira, J., Perez, A.T., 2007. Long-term assessment of particulate matter using CHIMERE model. Atmospheric Environment 41, 7726-7738.

Passant, N.R., 2002. Speciation of U.K. emissions of non-methane VOC, AEAT/ENV/ 0545. AEA Technology. Abingdon, United Kingdom.

Puxbaum, H., Caseiro, A., Sánchez-Ochoa, A., Kasper-Giebl, A., Claeys, M., Gelencsér, A., Legrand, M., Preunkert, S., Pio, C., 2007. Levoglucosan levels at background sites in Europe for assessing the impact of biomass combustion on the European aerosol background. Journal of Geophysical Research 112, D23S05.

Schmidt, H., Derognat, C., Vautard, R., Beekmann, M., 2001. A comparison of simulated and observed ozone mixing ratios for the summer of 1998 in Western Europe. Atmospheric Environment 35, 2449-2461.

SMN (Serviço Meteorológico Nacional), 1974. Atlas Climatológico de Portugal, Lisboa.

Stern, R., Builtjes, P., Schaap, M., Timmermans, R., Vautard, R., Hodzic, A., Memmesheimer, M., Feldmann, H., Renner, E., Wolke, R., Kerschbaumer, A., 2008. A model inter-comparison study focussing on episodes with elevated PM10 concentrations. Atmospheric Environment 42, 4567-4588.

Stohl, A., Williams, E., Wotawa, G., Kromp-Kolb, H., 1996. A European inventory for soil nitric oxide emissions and the effect of these emissions on the photochemical formation of ozone. Atmospheric Environment 30, 3741-3755.

USEPA (United States Environmental Protection Agency), 2009. Cleaner Burning Wood Stoves and Fireplaces Available online at http://www.epa.gov/ woodstoves/basic.html.

Vautard, R., Builtjes, P., Thunis, P., Cuvelier, K., Bedogni, M., Bssagnet, B., Honoré, C., Moussiopoulos, N., Schaap, M., Stern, R., Tarrason, L., van Loon, M., 2007. Evaluation and intercomparison of ozone and PM10 simulations by several chemistrytransport models over 4 European cities within the City-Delta project, 2007. Atmospheric Environment 41, 173-188.

Vautard, R., Bessagnet, B., Chin, M., Menut, L, 2005. On the contribution of natural Aeolian sources to particulate matter concentrations in Europe: testing hypotheses with a modelling approach. Atmospheric Environment 39, 3291-3303.

Vestreng, V., 2003. EMEP/MSC-W Technical report. Review and Revision. Emission data reported to CLRTAP. MSC-W Status Report 2003. EMEP/MSC-W Note 1/2003. ISSN: 0804-2446.

Vixseboxse, E., Leeuw, F., 2007. 2005 Annual Member States Reporting on Ambient Air Quality Assessment ('The Questionnaire'). European Topic Centre on Air and Climate Change (ETC/ACC) ETC/ACC Technical Paper 2007/4 November 2007. Netherlands Environmental Assessment Agency (MNP), Bilthoven, The Netherlands. 